\title{
KIMBERLITE ALMANAC
}

\author{
James Gurney ${ }^{1}$, Mike Baumgartner ${ }^{1}$, Eva Anckar², John Gurney ${ }^{1}$, Tom Nowicki ${ }^{3}$, Herman \\ Grutter $^{3}$, Megan Coetzee ${ }^{2}$, Neil Mason-Jones ${ }^{1}$ \\ ${ }^{1}$ Mineral Services, South Africa; ${ }^{2}$ UCT Kimberlite Research Group, South Africa; ${ }^{3}$ Mineral Services, Canada
}

\section{INTRODUCTION}

Primary diamond deposits world-wide show large variations in size, shape, petrography and mineralisation. A world-wide almanac summarising these and other related features has been assembled for a selection of key kimberlite localities utilising, amongst other tools, a custom designed computer application. This application facilitates the integration of petrographic, mantle macrocryst, and micro- and macro-diamond information. Data is stored in a relational SQL server database with a customised Microsoft Access front end and various graphing and reporting utilities.

The petrography component of this application allows for the description and categorisation of the various phases in the ore body. The mineral composition component screens and classifies the mantle macrocryst compositions, and identifies diamond potential as indicated by macrocryst compositions and abundances. Where the information is available, micro- and macrodiamond and diamond inclusion information has been integrated with the petrographic and mineral compositional assessments to allow comparisons to be made on a global basis.

The work demonstrates the combined usefulness of petrography, mantle macrocryst and micro-diamond characteristics in early stage assessment of diamondiferous kimberlites and lamproites. It also allows comparisons between diamond characteristics and paragenesis, illustrates several fundamental aspects of diamond formation that have general applicability, and demonstrates the importance of orientation studies for newly discovered kimberlite fields.

The following 4 pages provide examples of the general locality, petrography, and mineral composition information collated on the Finsch kimberlite. This kimberlite was discovered in 1960 near the town of Postmasburg in the Northern Province of South Africa, and has been in production since 1963.

\section{FINSCH EXAMPLE DATA SOURCE REFERENCES}

Clement, C.R., 1982. A comparative geological study of some major kimberlite pipes in the northern Cape and Orange Free State. Unpub. PhD thesis, Univ. Cape Town, South Africa.

De Beers Annual Reports. 1987 to 2000.

Gurney, J.J., Harris, J.W., \& Rickard, R.S., 1979. Silicate, oxide inclusions in diamonds from the Finsch kimberlite pipe. Proc. $2^{\text {nd }}$ Inter. Kimberlite Conf. In: F.R. Boyd, H.O.A. Meyer (eds), Kimberlites, Diatremes, Diamonds: Their Geology, Petrology, Geochemistry, Am. Geophys. Union, pp 1-15.

Haggerty, S.E., Raber, E. \& Naeser, C.W., (1983) Fission track dating of kimberlitic zircons. Earth and Planet. Sc. Letter, 63, 41-50.

Mining Mag., 1984. Progress at Finsch diamond mine, South Africa. 151, pp 375-377.

Shee, S.R., Gurney, J.J., \& Robinson, D.N., (1982) Two diamond bearing peridotite xenoliths from the Finsch kimberlite, South Africa. Cont. Miner. Petrol., 81, pp 79-87.

Smith, C.B., Allsopp, H.L., Kramers, J.D., Hutchinson, G. \& Roddick, J.C., (1985) Emplacement ages of Jurassic-Cretacious South African kimberlites by the Rb-Sr method on phlogopite and wholerock samples. Trans. of the Geol. Soc. South Africa, 88, pp 249-287.

Contact: M C Baumgartner, PO Box 38668 Pinelands, Cape

Town, South Africa, 7340, E-mail:

mike.baumgartner@minserv.co.za 


\section{FINSCH}

\section{Locality Information}

Region

Country

District

District Detail

Latitude

Longitude

Elevation ( $\mathrm{m}$ )

General Comment
AFRICA

SOUTH AFRICA

Postmasburg

$165 \mathrm{~km}$ west of Kimberley

$-28.35$

23.45

1534

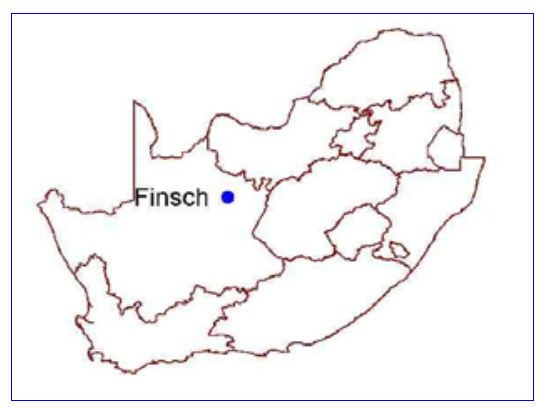

Location of Finsch mine in South Africa

Discovered by prospectors Finscham and Schwabel who had prospecting rights for asbestos, from which the name "FINSCH" was derived. One of the most technologically advanced mines in the world.

\section{Diamond Production}

Year of Discovery

1960

\begin{tabular}{|lllc|}
\hline From & To & Owners & Mined \\
\hline 1963 & present & De Beers & $\square$ \\
1961 & 1963 & Finsch Diamonds & $\nabla$ \\
& & & \\
& & & \\
& & & \\
\hline
\end{tabular}

\section{Postal Address}

Central Mines

$\mathrm{P} O \mathrm{Box} 7$

Lime Acres

8410

South Africa

Telephone

+27 (53) 3859505

Fax

+27 (53) 3859304

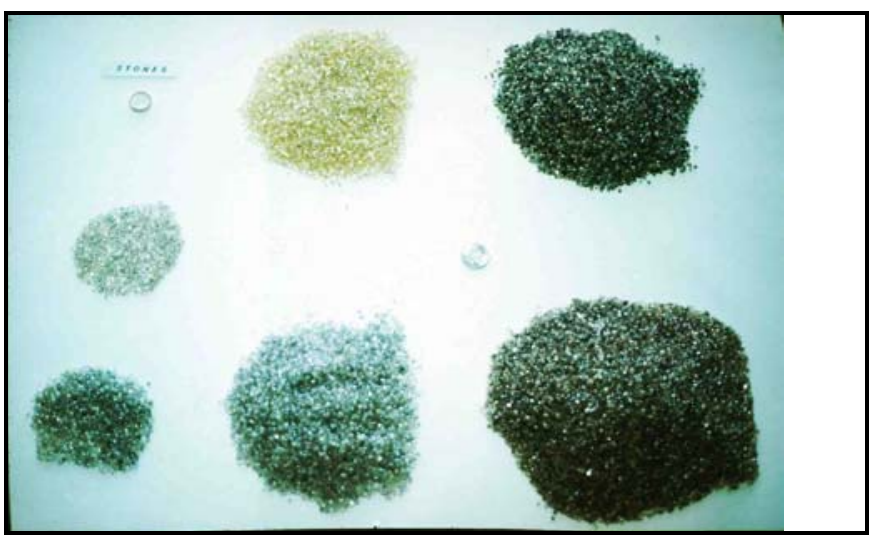

Production at Finsch mine 


\section{Geology}

$\begin{array}{ll}\text { Lithology } & \text { Gp II Kimberlite } \\ \text { Intrusion Shape } & \text { Circular } \\ \text { Intrusion Type } & \text { Pipe }\end{array}$

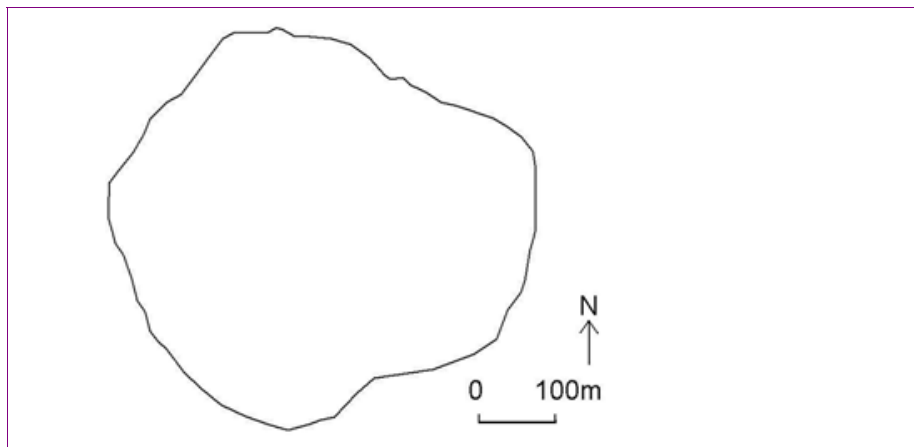

Rock types present

Sketch of the Finsch pipe at the $52 \mathrm{~m}$ level. From: Clement (1982)

Upper Facies

Hypabyssal

Surface area (ha)

17.9

Length ( $m)$

535

Width (m)

460

Locality Details

8 discrete intrusions recognised, namely two TKB and $6 \mathrm{HYP}$. The F1 (TKB) intrusion dominates the pipe; 6 HYP intrusives within $\mathrm{F} 1$.

Matrix Mineralogy

Mantle Xenolith Present Rare peridotitc and eclogitic xenoliths recovered

Host Rocks Ghaap Plateau dolomite formation

Cover Material

Cover Thickness $(\mathrm{m}) \quad 0$

\section{Basement Age}

Basement Lithology

Table of Kimberlite Ages

\begin{tabular}{|lll|}
\hline Age (Ma) & Dating Method & Reference \\
\hline $91.0 \pm 4.6$ & Fission track & Haggerty et al (1983) \\
$97 \pm 42$ & U-Pb (whole rock) & Kramers \& Smith (1983) \\
94.1 & U-Pb (zircon) & Davis (1977) \\
$118.4 \pm 2.2$ & Rb-Sr (phlog, whole rock) & Smith et al (1985) \\
\hline
\end{tabular}




\section{Petrography}

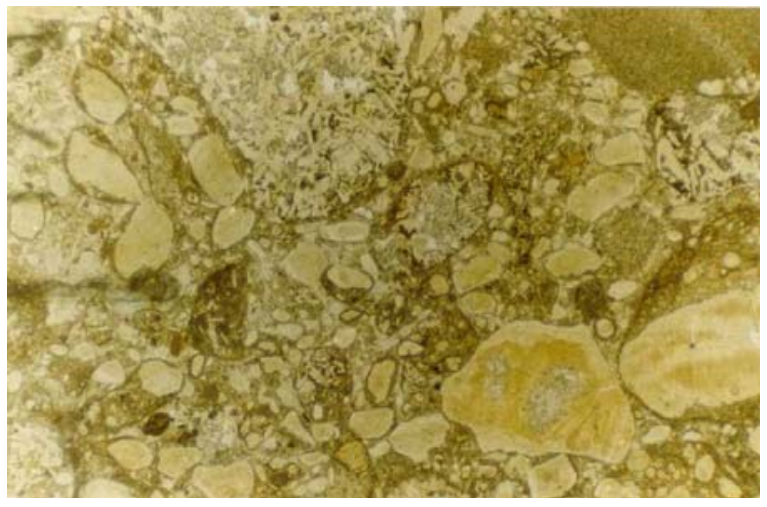

General view of the F1 TKB in the Finsch pipe. Numerous pelletal lapilli are evident, although many small lapilli, or lapilli with relatively thin mantles of kimberlite material, are not always easy to discern. Country rock fragments consist mainly of dolerite or basalt of Karoo age. Note the relative paucity of sedimentary inclusion. Large, altered (yellowish), olivine grains are prominent. FOV $=5 \mathrm{~mm}$. From Clement (1982)

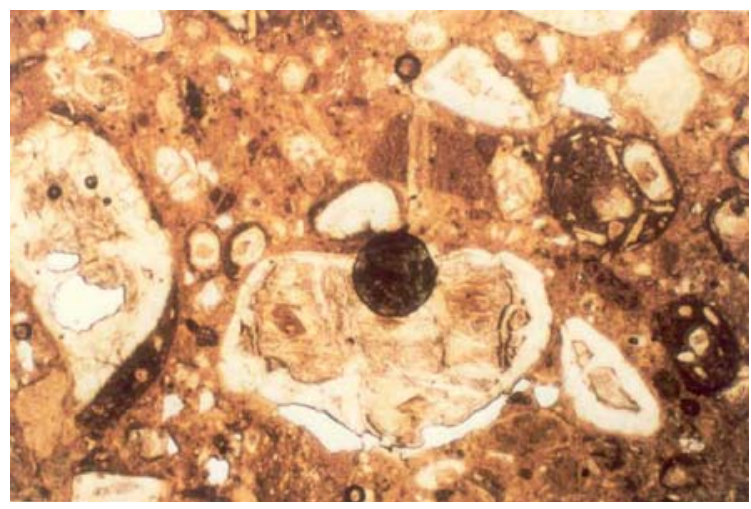

General view of pelletal lapilli, olivine pseudomorphs and microxenoliths in the F1 TKB. The specimen is extensively altered (weathered) and the coarse components occur in a base which now consists primarily of clay. FOV $=2 \mathrm{~mm}$. From: Clement (1982)

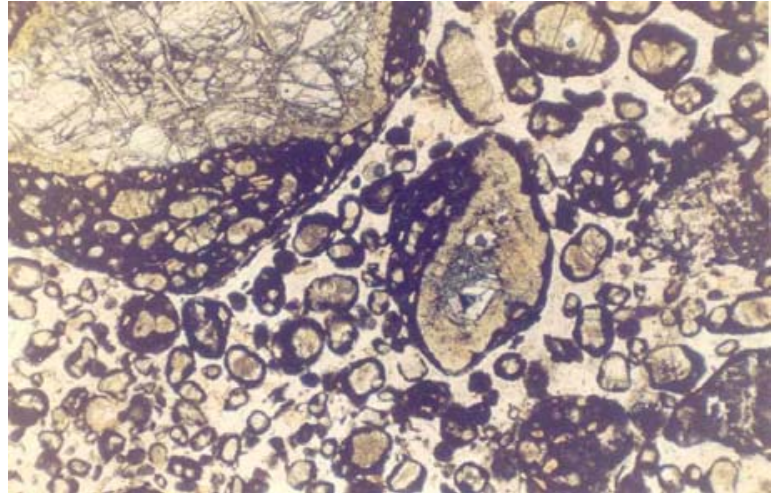

Globular segregations in the main segregationary-textured zone of the F2 intrusion in the Finsch pipe. Note the paucity of country rock xenoliths in F2. Although for the most part only small globular segregations are illustrated here many of these bodies approach or even exceed $10 \mathrm{~cm}$ in diameter. FOV $=5 \mathrm{~mm}$ From: Clement (1982)

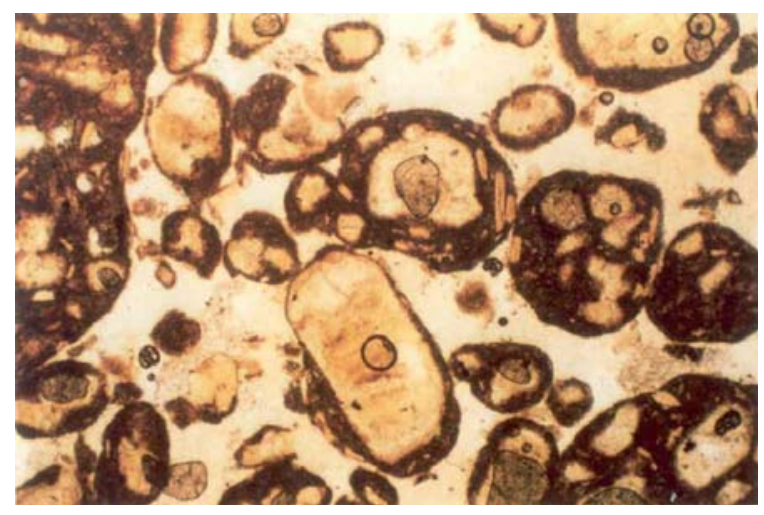

Globular segregations in the F2 kimberlite in the Finsch pipe. The groundmass of segregations consist mainly of fine-grained phlogopite and diopside. Phlogopite and altered olivine phenocrysts are prominent. Concentric alignment of elongate phenocrysts is apparent in some segregations. The intersegregation matrix consists mainly of serpentine with minor calcite. Many globular segregations have more-or-less centrally located kernels composed mainly of altered (serpentinized) olivine grains. FOV=3.5mm. From: Clement (1982). 

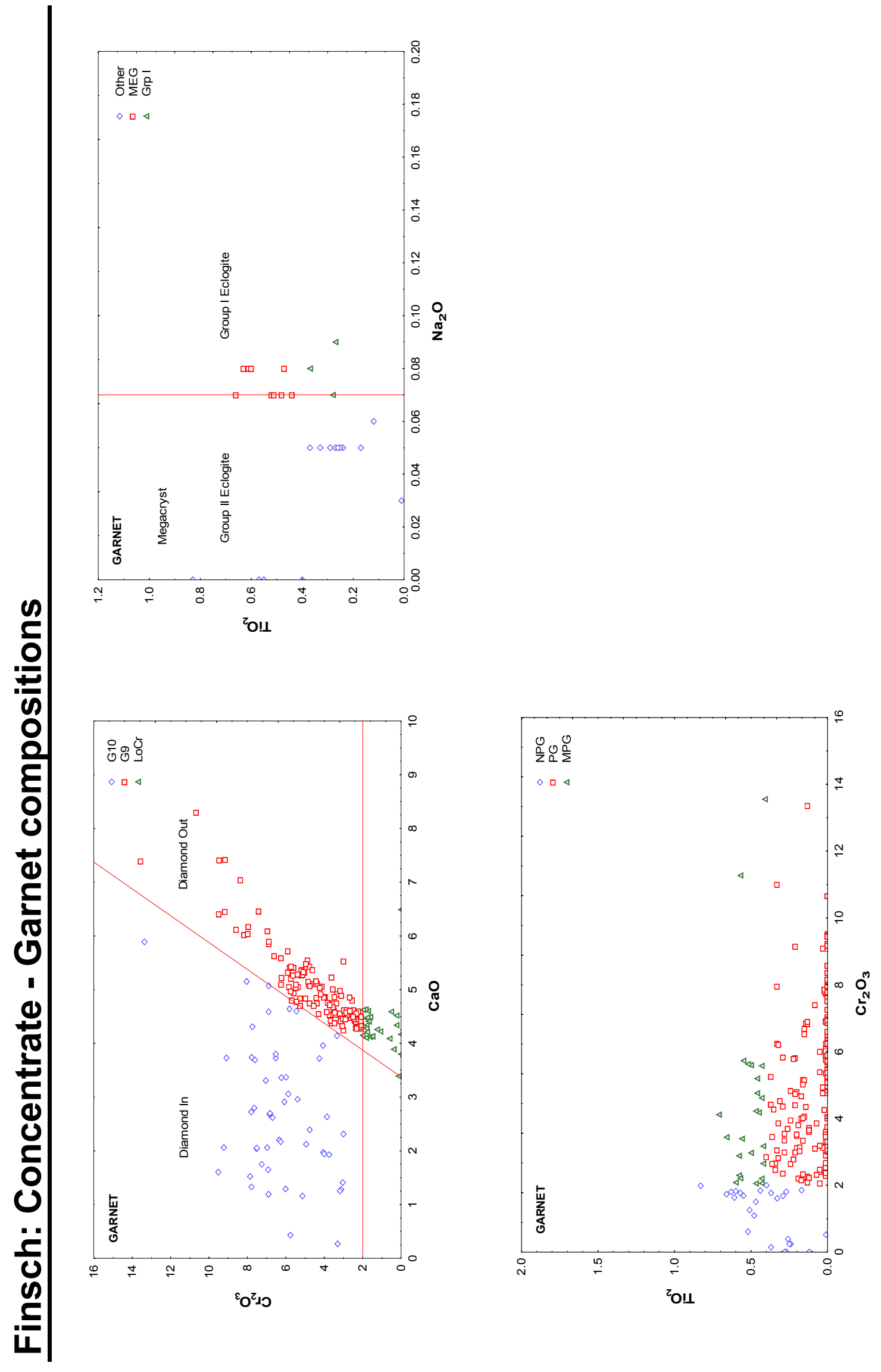